\title{
A REDIVISION OF LABOUR: VICTORIA'S WAGES BOARDS IN ACTION, 1896 - 1903*
}

With the 1896 Factories and Shops Act, the Victorian legislature took a pioneering step towards wage regulation in manufacturing industry. The new Act established six Wages Boards to cover furniture-making, baking, bootmaking and three branches of the clothing trades. Each Board was to comprise equal numbers of employer and employee representatives under a 'neutral' chairman with a casting vote, and each was equipped with power to specify mandatory minimum wage levels and the proportions of learners to be employed in its trade.

As is well known, the measure was less the brainchild of the labour movement than of the liberal Christian small-bourgeois and professionals of the Anti-Sweating League. ${ }^{1}$ The liberal anti-sweaters had a restricted vision of the prevailing economic crisis. They sought particularist, moralistic explanations for the misery engulfing the working class in the $1890 \mathrm{~s}$, and fashioned their legislation accordingly. They attributed the near-universal erosion of wage standards to the greed of a small number of unscrupulous employers who had taken advantage of the glut of labour to reduce wages, undercutting the business of the respectable majority and eventually compelling them to follow suit. The solution seemed straightforward: the state should provide a neutral ground on which employers and employees could meet and, through collective bargaining, formulate a common attack on the unscrupulous minority. Only the sweaters would suffer: wages would rise, the domestic market would revive, profits and employment would increase, and all men of good will would prosper.

The liberals did not envisage this as requiring any large-scale state intervention. The state would merely provide the mechanism, then enforce the Boards' decisions. Their optimism, however, proved to be misplaced. Consensus was far more elusive than they had expected. The Wages Board system soon became the centre of a political tug-o'-war. On the one hand, labour was demanding that the system be extended; on the other, employer opposition mounted. Bowing to a barrage of requests from labour, the legislature enacted a new law in 1900, allowing Wages Boards to be established on a resolution of either House. This was followed by a spate of expansion; by mid-1901 32 new Boards had been created. But during 1901-2 employer opposition stiffened. In 1903, with the Kyabram movement mobilising conservative support for a reduction of state powers, and a powerful backlash against the Wages Boards ris-

\footnotetext{
* Thanks to Raelene Frances and Marilyn Lake for offering stimulus, support and advice at several stages in the preparation of this essay.

' For general discussions of the Boards' origins, see P. Macarthy, 'Victorian Wages Boards: their origins and the doctrine of the living wage', Journal of Industrial Relations, vol. 10, 1968, pp. 118-19; J. Rickard, Class and Politics: New South Wales, Victoria and the Early Commonwealth, Canberra 1976, pp. 88-115; K. Rollison, 'The Development of Wages Boards in Victoria 1896-1907', unpublished paper delivered to Australian Historical Association Conference, 1984, pp. 1-3.
} 
ing among the urban bourgeoisie, the liberal Peacock administration was swept from office.

Under the conservative Irvine, it appeared that the Wages Boards might be abolished. Indeed, the Boards did lapse for a time when the Legislative Council held up the renewing legislation. When the Act was eventually renewed in 1903, the Wages Boards' powers were substantially diluted, and an Industrial Appeals Court was introduced, with power to review Wages Board decisions. ${ }^{2}$ Little remained of the original vision but a 'tame cat' wage regulation system which Victorian employers could counterpose to the emerging federal arbitration courts.

Yet if men's earnings are taken as an index of labour's gains from the Wages Board system prior to 1903, it is difficult to explain the vehemence of the employer reaction. As Macarthy has pointed out, the minimum wages specified for men were highly variable, and only skilled tradesmen approached the $42 \mathrm{~s}$ per week benchmark established as a living wage by the Harvester judgement in 1907. ${ }^{3}$ A mere handful of highly skilled workers and supervisory hands gained the pre-depression skilled wage standard of $60 \mathrm{~s}$ per week. Most tradesmen's wage levels ranged between $45 \mathrm{~s}$ and $50 \mathrm{~s}$, with the bootmakers going as low as $36 \mathrm{~s}$. For 'general' hands, or men without a trade, rates were lower on the whole. Although in a few industries labourers were awarded wages of between $36 \mathrm{~s}$ and $40 \mathrm{~s}$, in other cases general hands' wages ranged as low as $25 \mathrm{~s}$ or $30 \mathrm{~s} .{ }^{4}$ Quite commonly the minimum wages set were substantially below the ruling market rates for experienced hands. ${ }^{5}$

The primary significance of the early Wages Board determinations, and the roots of the employer backlash, lay not so much in the increases which the Boards prescribed for adult men as in their attempts to influence the division of labour within the factories. To comprehend the Boards' impact and to understand the labyrinthine patterns of class conflict, compromise and tactical alliance which emerged during their deliberations, it is necessary to appreciate the changes that had occurred in the capital structure of manufacturing industry during the 1880 s and 1890 s and the reorganisation of the labour process which they entailed. Specifically, the agenda which labour brought to the early Wages Boards represented a reaction to the perceived marginalisation of craftsmen, and of adult men generally, within the larger factories; an attempt to reinstitute some control over entry to the trades by restricting outwork, insisting on direct employment rather than subcontracting as a norm and penalising employers

\footnotetext{
${ }^{2}$ For a general description of the sequence of legislative change, see P. Davey, 'Wages Boards in Victoria, 1896-1920', Ph.D. thesis, University of Melbourne 1975, esp. pp. $61 \mathrm{ff}$.

${ }^{3}$ Macarthy, op. cit., pp. 124-5.

${ }^{4}$ These and later citations of Wages Board minima are taken from the compilations of Wages Board determinations included as appendices to the Reports of the Chief Inspector of Factories and Shops (CIFS) 1901-1903, Victorian Parliamentary Papers (VPP) 1901, vol. 2, no. 28; 1902, vol. 2, no. 16 and 1903, vol. 3, no. 14 .

${ }^{5}$ See e.g. evidence to the Royal Commission appointed to Inquire in the Factories and Shops Act (RCFS), VPP, 1902-3, vol. 2, no. 31, qq. 6048, 6715, 7710, 8040, 8101, 8550, 11773.
} 
who did not make provision for training their juvenile hands; and a campaign to reassert the primacy of men's claims to receive a family wage. How far labour was able to put its agenda into effect was to depend very largely on whether it succeeded in gaining support across class lines, either from dissident employers or from the chairmen of the Boards. The processes of the early Wages Boards therefore shed a considerable amount of light, not only on the internal structure and politics of the working class, but also on the basis of the strategic alliance with sections of the bourgeoisie which was so much a feature of the organised labour movement during this period.

The craftsman, as both master and employee, occupied a pivotal position in the early development of Victorian manufacturing industry. In small-scale, labour-intensive manufacturing firms, the skills of the craftsmen were indispensable. 'Finished' craftsmen were expected to be able to construct a wide range of articles from start to finish without close supervision, and to possess a sufficient breadth of experience to allow them to adapt readily to the quirks of new masters and new workplaces. Furthermore, in key steps of the production process they were required to exercise a fine combination of design skills, speed, accuracy and caution, coupled in all but the lightest trades with a considerable amount of sheer physical strength. This was acquired only through extensive experience and instruction. Within the workshop, other hands' roles were defined by their relationship to the craftsman: they were apprentices, indentured to a particular master for periods of up to seven years, or 'helpers', assisting the craftsman and subject to direction from him. Yard hands and stablemen were expected to keep to their own territory, away from the production process proper. The small scale and low capitalisation of manufacturing enterprises were reflected in the ease of mobility from the status of operative to that of small employer. ${ }^{6}$

The growth of population and the rise of factory production during the 1880 s placed the craft system under strain. With tariff protection, mercantile capital had moved into import-substitution manufacturing. An expanding local and intercolonial trade supported factories of unprecedented scale, many of them owned by men who had no direct experience of work in the industry and scant respect for craft prerogatives. Increasingly, production was standardised, mechanised and sub-divided, and craft labour was spread more thinly. At one extreme, in tobacco-making and biscuit manufacture, craftsmen stayed on, if at all, as supervisors of a largely juvenile workforce. ${ }^{7}$ In tailoring and boot-making, design and cutting were hived off from making up, and over the 1880 s the cutters and clickers gained recognition as elite branches of the trades, each with its own union. Furthermore, tailors and cutters in the clothing trade began

6 See e.g. discussion in R.T. Fitzgerald, The Printers of Melbourne: the History of a Union, Melbourne 1967, p. 28.

7 For examples see Royal Commission on Employees in Shops (RCES), Minutes of Evidence, VPP, 1884, vol. 3, no. 39, qq. 3059ff (tobacco) and wages books in T.B. Guest Collection, Melbourne University Archives (biscuit-making). 
increasingly to function as middlemen, setting up small suburban workrooms which offered employers a ready means of circumventing the Tailoresses' Union's attempts to improve wages for women employed in the factories. ${ }^{8}$

The rise of the factory system was accompanied by an increase in craft union activity. The craft unions' standing aims had been to protect the craftsmen's status, limit the proportions of juveniles employed and maintain a set of wage standards which prescribed an orderly progression from the token wage of the apprentice to the far higher rates paid to fully-fledged tradesmen. Their usual tactics were to establish a log of wages by man-to-man bargaining with a nucleus of 'fair' employers, backed up by selective industrial action and consumer boycotts. ${ }^{9}$ By these means many craft unions were able to limit the subdivision of labour and secure substantial advances in wages during the 1880 s. Significantly, however, all experienced some difficulty in enforcing controls over entry to their trades. With their strength confined to urban areas, they could not police country employers, and even in the cities the apprenticeship system was constantly under threat from employers who tried to buy apprentices away from their masters by offering them better-paid work as 'improvers', not subject to formal indentures. ${ }^{10}$

If some aspects of the craft system were weakening in the $1880 \mathrm{~s}$, the following decade saw its wholesale dismemberment in many trades. The crises of the early $1890 \mathrm{~s}$ had profound repercussions in manufacturing industry. The growth of manufacturing in the 1880 s had been geared towards supplying the three leading sectors of the economy - pastoralism, urban construction and the state-owned transport and communications network - and providing for the requirements of a rapidly growing population. In the early 1890 s the demand for capital goods plummeted as the leading sectors stagnated. The market for consumer goods also slumped; unemployment and under-employment rose, wages were cut and the inflow of immigrants turned into an exodus. There was a strong downward pressure on prices. In the labour-intensive light industries, competitive pressures were intensified by the proliferation of small shops set up by craftsmen displaced from their earlier employment. ${ }^{11}$ Many manufacturing firms closed, and those that survived did so only by implementing substantial reductions in their labour costs.

Retrenchment took a variety of forms. ${ }^{12}$ Many firms cut wages across the board, though sometimes the clerical and supervisory staff were exempted. All

\footnotetext{
${ }^{8}$ Factories Act Inquiry Board, Minutes of Evidence, VPP, 1895-6, vol. 3, no. 44, evidence of J.A. Reid, q.889; also W.H. Ellis, qq. $731 \mathrm{ff}$. See also R. Brooks, 'The Melbourne Tailoresses' Strike 1882 1883: An Assessment', Labour History, no. 44, 1983, esp. p. 36.

${ }^{9}$ See e.g. Victorian Operative Bootmakers' Union, Minutes of General Meetings, ANU Archives of Business and Labour, T5/1/2-3; Fitzgerald, op. cit., pp. 33, 56ff.

${ }^{10}$ CIFS, 1888, VPP, 1889, vol. 3, no. 3, esp. p. 5; Melbourne Typographical Society, Membership Applications, 1888-9; RCES, evidence of R. Middleton, qq. 3837-8.

"See e.g. RCFS, evidence of C. Anderson, qq. 12529, 12533; also Wages Board History files, Public Record Office of Victoria, VPRS 5466, 37 (Cigar Makers) and 98 (Ham and Bacon). 12 The discussion which follows summarises preliminary results of a larger study of the 1890s
} 
but the most productive and 'reliable' workers were dispensed with, enabling trade union activists to be weeded out systematically. The labour process in the factories was more and more minutely subdivided, permitting craftsmen to be replaced by lower-paid workers, often juveniles or women. Even in the trough of the depression, and far more commonly in the early stages of the recovery, employers were able to muster the funds to bring in new machinery, much of it American-made, to handle sections of the production process for which handwork had previously been essential. The mechanisation process was largely piecemeal: most machines performed only a single operation, but at a speed far in excess of that possible with hand-work, and often at a low capital outlay. The mechanisation of a few strategic sections of the production process could, however, have wide ramifications, as it enabled employers to reorganise and subdivide the rest of the process, breaking up the long and varied sequence of tasks which had characterised craft work. Craft workers could not be completely eliminated: in most factories there was some work which could be performed most economically by hand, as production volumes were not sufficient to justify capital outlays on machinery. But the bread-and-butter of the trades was increasingly mechanised, providing steady employment at low wages for untrained workers. Some experienced hands with craft skills took on a supervisory role; but other craftsmen were often left standing around waiting for intermittent work on the non-standard jobs which the machines could not handle. ${ }^{13}$

Several of the craft unions fought hard to resist subdivision. The boot trade union resisted step-by-step through the years to 1893, the campaign culminating in a costly series of strikes in 1893-4 which were broken by the importation of machinery and the introduction of strike-breakers, recruited in one instance from the Port Melbourne casual labour yard. ${ }^{14}$ But the craft unions could not hold their membership in a labour market where 'able-bodied men were offering to work for little more than their food'. ${ }^{15}$ In any event, they seldom had the support of women, juveniles or machinists, who were increasingly forming the core of the factory workforce. Though by the time the trough of the depression was reached in 1894-5 many of the craft unions had attempted to broaden their membership base by relaxing entry restrictions, it was too late. ${ }^{16}$ Few could even induce employers to negotiate, let alone mount a successful strike, and they had little to attract new members.

The 1890s therefore marked a crisis period for craft unionism, with wide

${ }^{13}$ See RCFS, evidence of J. Hyman, q. 7213, T. Deslandes, q. 7491, A. Dobson, qq. 10275-6. Also comments by J. Hogan in minutes of Wages Board review, p. 48, in Boot Trade file, VPRS 5466, 11. ${ }^{14}$ See Operative Bootmakers, T5/1/3, esp. 27 June 1892, 13 February 1894, 16 February 1894. Also J. Hyman to RCFS, qq. 7210, 7295. For recruitment from Port Melbourne, see A. McLachlan's evidence, RCFS, q. 7626.

is Report of the Secretary, Department of Neglected Children and Reformatory Schools, VPRS 5690 no. 2,1893 , p. 3.

16 See e.g. Operative Bootmakers, T5/1/3, 15 January, 25 February, 25 March, 29 July 1895; Amalgamated Society of Engineers, Ballarat Branch membership records at ANU Archives of Business and Labour, E221/42. 
ramifications for the industrial working class as a whole. The exclusivism of the craft unions had confirmed the subordinate status of juveniles, women and the unskilled within the labour market, helping to constitute them as a reservoir of cheap labour which could be brought in to dislodge craftsmen wherever the technical basis of the crafts' skill monopoly was undermined by subdivision and mechanisation. Even the revival in trade after 1895 did little to improve the craft unions' position. By the mid-1890s craft methods survived undiluted only in the small 'quality' shops. Moreover, it was not these shops but the large factories that led the recovery by tapping intercolonial markets, in the process accumulating capital for further mechanisation. Though employment became steadier and earnings less erratic in the later 1890 s, prices also rose and the barriers to the reemployment of craftsmen remained high. ${ }^{17}$ Broadly, this was reflected in the changing gender and age composition of the manufacturing workforce. In 1890 males comprised almost three-quarters of the workforce in Victorian registered factories. In 1895 this had slipped to 67 per cent, and by 1900 to 64 per cent. Adult men constituted about 51.9 per cent of the workforce in $1890,49.5$ per cent in 1895 and 47.2 per cent in 1900 . Significantly, too, the gain in female employment was entirely among adult women; the female manufacturing workforce was beginning to acquire an air of permanence. ${ }^{18}$

These trends implied persistent unemployment and under-employment among established craftsmen. If the cry after the gold rushes was 'what shall we do with our boys?', that after the collapse of the land boom was 'what shall we do with our men?' ${ }^{19}$ In 1897 Tocsin invoked labour's First Commandment - 'Thou shalt not scab' - against working women and commented that:

women are ... the most dangerous and the most numerous class of 'free labourers'. And every advance in machinery rendering it possible to do without the acquired experience of trained artisans makes the day come nearer when the men of the community shall be absolutely idle, and their places taken by low-paid and poorly-fed women. ${ }^{20}$

Similarly, at an 1898 boot trade meeting the anarchist 'Chummy' Fleming complained that "in the "paradise for the working man" ... the people who were doing the work were women, girls and helpless children' ${ }^{21}$

The younger generation of male factory workers faced problems of their own. The hierarchy within the factories had an increasingly wide base and narrow apex. The de-skilling of factory work was producing a truncated career structure in which few new recruits could expect to graduate to craft status; the main path to advancement was coming to lie in the acquisition of supervisory

${ }^{17}$ On rising prices, see P. Macarthy, 'Wages in Australia 1891 to 1914', Australian Economic History Review, vol. 10, 1970, pp. 66-7.

18 Calculated from CIFS, 1890, 1895 and 1900 (1890 figures for adult males derived using proportions from 1891 census).

${ }_{19}$ Australasian Typographical Journal, April 1888.

${ }^{20}$ Tocsin, 18 November 1897 . Thanks to Rodney Benjamin for this reference. One might ask: who would do the housework?

${ }^{21}$ Age, 15 February 1898; Argus, 15 February 1898. 
responsibilities. Even the progression from boys' to adult wages was not automatic; by the late 1890 s there were numerous instances of young men in their mid-twenties being paid $25 \mathrm{~s}$ a week or less, well below the pre-depression unskilled standard of around $36 \mathrm{~s}$ to $40 \mathrm{~s} .{ }^{22}$ The marriage rate had tumbled at the time of the initial economic crisis in the early 1890 s, and remained low for the rest of the decade. ${ }^{23}$ There was rising concern that low juvenile wages were acting as the thin end of the wedge for a general lowering of men's wage standards which would erode the family wage and in turn force more married women on the labour market.

The shifting composition of the manfacturing labour market, coupled with the continuing stagnation of the construction industry, which had been the main alternative avenue of manual employment for men in the cities, had profound implications for the division of labour within the family. Adult male unemployment had reached close to 30 per cent in the early 1890 s, and a substantial proportion of those still employed had been working less than a full week; even in the late 1890 s adult male unemployment persisted at around ten per cent. There had also been an exodus of men from Melbourne, many leaving their families to fend for themselves. ${ }^{24}$ It became imperative for other family members to find work, even at low wages. Over the decade, the workforce participation rates of boys under twenty increased marginally, and of adult women substantially. But the range of jobs in which women were employed remained narrow. In 1891, almost 82 per cent of the women working in registered factories in Victoria were in the apparel and textile trades, and the figure was still 75 per cent in $1901 .^{25}$ The rush of new workers into a very restricted range of jobs, many of them in industries where subcontracting and outwork were endemic, accentuated the downward spiral of wages. By the middle of the decade, female and juvenile wages had fallen to such low levels that three or four other family members had to work to compensate for the loss of an unskilled man's income. ${ }^{26}$ The fragmentation of the workforce resulting from the rise of subcontracting, the reluctance of unorganised workers to place their jobs in jeopardy by holding out for better terms, and the victimisation of 'agitators' gave little hope of the situation improving through industrial action in the short term.

Whatever the inadequacies of the Wages Board system, it alone appeared to offer a way out of this impasse. From about 1897 there were signs of a revival of

${ }^{22}$ Examples can be found in the T.B. Guest wages books; see also RCFS, evidence of M. Gilmore, qq. 6287-98; G. Dupree, q. 6637; W. Bayst, qq. 9396-7. Also letter from Confectioners' Union to Minister of Labour, 1 August 1900 in VPRS 5466, no. 44.

${ }^{23}$ See Victorian Year Books, 1892-9.

${ }^{24}$ For a set of unemployment estimates see Macarthy, 'Wages in Australia', op. cit., pp. 20, 24. The desertion of families is discussed in VPRS 5690, nos. $2 \mathrm{ff}$, and in C. Strong's evidence to the Royal Commission on Old Age Pensions, VPP, 1898, vol. 3, no. 28, q. 444.

${ }^{25}$ See CIFS, 1891 and 1901 .

${ }^{26}$ Assuming the man was earning the old unskilled standard of around 36s, and that a woman and three juveniles aged 19,16 and 14 would earn around $15 \mathrm{~s}, 12 \mathrm{~s}, 8 \mathrm{~s}$ and $2 \mathrm{~s} 6 \mathrm{~d}$ respectively. This is a rough estimate only. Much would depend on whether the juveniles were boys or girls, and whether the woman was able to take factory work. 
interest in trade unionism. ${ }^{27}$ Old unions began to recruit again and new unions were formed in several industries. With the assistance of Trades Hall and AntiSweating League activists, this discontent was channelled into a series of campaigns for new Wages Boards. Each campaign involved mustering signatures for petitions, despatching deputations and, after a Board was appointed, putting together a union ticket for the labour positions, overseeing the progress of negotiations and monitoring any anomalies arising from deficiencies in the determinations' coverage or enforcement. ${ }^{28}$ The whole process gave focus to the unions' activities and required only a bare minimum of support on the ground.

The crux of the agenda that labour brought to the Boards was the belief that men should have sufficient wages to allow them to support a family, and sufficient leisure time to permit them (if they so desired) to maintain their presence in the household. The Royal Commission which inquired into the Act in 1900-1 heard many complaints about the effects of long working hours on men's domestic life; one cook, for example, claimed that he had gone for seven consecutive days without seeing his children awake. ${ }^{29}$ To secure a family wage and shorter working hours, the unions looked to various mechanisms of labour market closure. The Wages Boards' powers to specify wage levels, limit working hours and restrict the proportions of learners offered almost infinite possibilities in this regard.

The Furniture Board's decisions illustrate practically the whole gamut of closure strategies adopted by the various Boards. The furniture trade had been included in the first set of Wages Boards mainly in the hope that the enforcement of minimum wages and standard hours would drive the Chinese out of the trade. To keep the Chinese out of the Board itself, its members were nominated, not elected. The all-white Board first met in 1897, and with little difficulty arrived at its first determination, which set the minimum for cabinetmakers at $7 \mathrm{~s} 6 \mathrm{~d}$ per day and established uniform opening and closing times to make it easier for the factory inspectors to detect any overtime being worked in the Chinese factories. ${ }^{30}$ The intended effect, however, was not achieved. The minimum wage was difficult to enforce in the Chinese factories; and, more fundamentally, the Chinese had developed a wide range of techniques (including a high level of specialisation and the use of nails, glues and cheap woods) that allowed them to compete successfully even with equivalent wages in a market where few purchasers could afford to pay more for their furniture simply for the satisfaction of knowing it was made by whites. ${ }^{31}$

Furthermore, the Board had other problems to contend with. The 'Euro-

\footnotetext{
${ }^{27}$ See Victorian Trades Hall Council Minutes, 1897-8, Victorian Trades Hall Collection, Melbourne University Archives. 28 The scope of the unions' activities is clear from a reading of the Wages Board history files at VPRS
5466 .

${ }^{29}$ RCFS, evidence of P. Ploog, q. 9202.

${ }^{30}$ VPRS 5466, 75; CIFS, 1896, in VPP, 1897, vol. 2, no. 11 ; RCFS, evidence of D. Fallshaw, esp. qq. $9409,9418 \mathrm{ff}$.

${ }^{31}$ Factories Act Inquiry Board, qq. 6088, 6167ff., 6232; RCFS, q. 9418; see also qq. 13064-5.
} 
pean' section of the trade was in a state of disarray. During the depression it had become common for craftsmen to be paid according to a degenerate system of piece-rates, known as 'lump' rates, which gave the employers considerable scope to introduce variations and additional details after the work had been started. ${ }^{32}$ Furthermore, displaced factory hands had set up their own small shops, sometimes dealing directly with the warehouses and undercutting the larger manufacturers, and sometimes hawking their wares in the streets of the inner suburbs. ${ }^{33}$ And many of the large employers had followed the path of mechanisation and subdivision. Low quality chairs, for example, were cut out by machines and merely knocked together by hand, often by unskilled men and juveniles. ${ }^{34}$ Apprenticeship had fallen into disuse, and craft methods were dying out in all but the first-class shops as the pace of work accelerated and 'scamping' the work became the order of the day. ${ }^{35}$

To reestablish some control over the labour market, the labour representatives proposed a ban on payment by the piece. This simultaneously made things harder for the Chinese, who had worked on piece-rates, prevented outworkers from dealing with the factories, and closed the main loophole which would have allowed employers to circumvent the minimum wage. The employers initially agreed to the ban, seeing it as a measure of compensation to the labour representatives for having conceded a lower rate of wages than the union membership hoped for. ${ }^{36}$ The ban subsequently persisted through two further sessions, in spite of a vociferous campaign by several large employers for the reintroduction of piece-rates. The ban was kept in place by the support of the less heavily mechanised employers, who had a vested interest in limiting the extent of subcontracting and who also feared that if uniform piece-rates were set, they would be a paying proposition only for the machine-made and not the handmade articles. ${ }^{37}$

A further step towards restricting entry was the limitation of juvenile labour. At the outset the labour representatives on the Board suggested that employers be allowed one apprentice 'for the shop', and one for every four journeymen thereafter. This was reduced at the employers' instigation; seeing a chance to put the very small shops at a disadvantage, they suggested a simple one to four ratio, which would not have allowed any apprentices to shops with less than four employees. ${ }^{38}$ The first determination also allowed one improver to each four journeymen and set improvers' wages on a far higher scale than apprentices' to encourage employers to indenture their juveniles. Finally, no provision was made for the employment of unskilled boy labour. This represented a departure from the practice in the factories, where boys had been

32 RCFS, evidence of T. Holdsworth, qq. 9915-6, J. Bowie, qq. $10438 \mathrm{ff}$.

${ }^{33}$ Ibid., evidence of D. Fallshaw, qq. 9426, 9877; see also Age, 22 July 1897.

${ }^{34}$ Ibid., evidence of A. Benness, qq. 9738-44.

${ }^{35} \mathrm{Ibid}$., evidence of T. Holdsworth, q. 9916.

36 Ibid., q. 9916.

${ }^{37} \mathrm{Ibid}$., evidence of D. Fallshaw, q. 9326.

38 Ibid., evidence of T. Holdsworth, q. 9916; VPRS 5466, 76. 
employed to clear up, fetch and carry, and make the journeymen's tea. Though the larger employers objected strenuously to the redefinition of their boys as learners, the chairman of the Board refused to agree to the recognition of unskilled labour, and some master craftsmen supported the Board's decision. ${ }^{39}$

The question of female labour was only brought up at the Board's second session. Women in the furniture trade were mainly employed finishing off softgoods. For this work, which fell within the customary definition of 'women's work', the Board set a wage rate of 20 s per week. ${ }^{40}$ But there were problems in areas in which male and female workers had been placed in direct competition. Under the 1900 Act the Board's powers were extended to cover, inter alia, the manufacture of wire mattresses. Weaving the mattresses by hand had been extremely hard and well-paid work, invariably performed by men. With the introduction of powered machines, however, women had been brought in at far lower rates. On the Board, the employees initially pressed for equal pay for women employed at this work. The employers dissented and on the chairman's casting vote the rates were finally set at $48 \mathrm{~s}$ for men and $32 \mathrm{~s}$ for women. ${ }^{41}$ The chairman also voted to introduce a wage of $45 \mathrm{~s}$ per week for varnishers, who the employers contended were merely unskilled boys. Though they had borne with the Board through so many restrictive decisions before, the employers' representatives walked out after the vote was cast; their co-operation was contingent on the Board's decisions not affecting their own balance sheets adversely.

Equal pay for women was suggested by labour representatives on at least five other Boards before 1903, with varying degrees of success. In each case the circumstances were broadly similar: an operation which had previously been an integral part of a skilled, masculine job had been hived off and mechanised for large-volume production, and women had been brought into direct competition with craftsmen. Though the labour representatives invariably couched their arguments in terms of equity, their clear intention was to exclude women. This strategy gained considerable support from the smaller employers, and resulted in some of the most controversial of the early Wages Board determinations.

The Pastrycooks' Union did not get employer support for its equal pay campaign. ${ }^{42}$ The Tinsmiths' Board, on the other hand, was marked by an unusual degree of unanimity: the specialist master tinsmiths, alarmed at the tendency for the jam and biscuit factories to make their own tins with machinery on the premises, supported the institution of a minimum rate of $46 \mathrm{~s} 6 \mathrm{~d}$ for all hands employed on soldering machines. As this implied that the women and juveniles working the machines should be paid only $1 \mathrm{~s} 6 \mathrm{~d}$ per week less than experienced tradesmen, it aroused an outraged protest from the jam

\footnotetext{
${ }^{39}$ VPRS 5466, 75 includes a note from Buesst and Bills Brothers dissociating themselves (1901); see also RCFS, qq. $9427,9453,9510,9700$.

40 This rate was set on the chairman's casting vote (Age, 20 July 1898).

${ }^{41}$ RCFS, qq. 9866f., 10085; the manufacturers' protests are included in VPRS 5466, 75.

42 See VPRS 5466, 135; also RCFS, qq. 8715, $11745,11762,11769$.
} 
manufacturers. ${ }^{43}$ Likewise, the largest employers in the cigar trade, Jacobs, Hart and Co., had brought in American machinery to allow them to employ women in stripping and booking the leaf. The Cigar Makers' Society and the other employers in the trade combined to set the minimum wages for this work at $40 \mathrm{~s}$ per week irrespective of gender. ${ }^{44}$ A similar coalition on the Brushmakers' Board carried through a determination based entirely on equal pay, fully realising that this would not meet with the approval of the two employers who had recently begun to employ women. ${ }^{45}$ Finally, the Clothing Board, which had long been marked by friction between the master tailors and the manufacturers of stock clothing, included in its 1901 determination a provision for equal pay for male and female seam pressers. ${ }^{46}$

The principle of equal or near-equal pay was not only applied to adult women. Although it was a long-standing custom to pay boys rather more than girls, ${ }^{47}$ equal pay for male and female learners was prescribed by the Cigar, Confectionery, Jam and Woollen Boards, and in many other trades the rates set for male and female learners were identical for the first three or four years of their employment. ${ }^{48}$

But of far greater significance was the application of equal pay rates in allmale trades. In fact, equal pay was the default position on all the Boards: unless a Board specifically prescribed pay differentials based on gender and age, minimum wages were set for all persons performing a designated function. While in the longer term this may have acted as a barrier to women's employment, its immediate intention was to redefine the boundaries between men's and boys' work.

Under the craft system the distinction between men's and boys' work had been enforced by the technical basis of the labour process itself. The long time taken for hands to become competent, the cost of damage to materials and the risks of allowing boys free rein on the shop floor, all enforced a division of labour in which boys were kept under supervision unless they were performing light, unskilled jobs. But many of the new jobs which emerged during the 1890 s were light and unskilled, though with the crucial proviso that many involved the use of potentially dangerous machinery. To keep boys in their place in the factories, it was necessary to establish an elaborate, and often artificial, system of classification which demarcated the jobs for which adult and juvenile rates were to be paid. This departure from customary norms met strong opposition from employers. As one complained, some of the work reserved for men was so easy that a 'man ought to be ashamed to do' it. ${ }^{49}$

43 Correspondence on the controversy is included in VPRS 5466, 193.

44 See VPRS 5466, 37.

45 VPRS 5466, 19.

46 RCFS, qq. 7861, 7922, 7951, 7954, 8001-3.

47 See appendices to CIFS reports $1895-1900$ for ruling wage rates.

48 These and subsequent comments are based on the summaries of Wages Board determinations in CIFS, 1900-2 and the files at VPRS 5466.

49 RCFS, evidence of H. Burgess, q. 6537; cf. W. Angliss at q. 12187. 
The first step towards restricting juvenile labour was to tie the employment of juveniles to the provision of training on the job. ${ }^{50}$ At least twelve of the Boards which brought determinations down before 1903 refused to make provision for the employment of youths other than as apprentices or improvers. A large proportion of the remainder limited the employment of unskilled juveniles, either by restricting the tasks at which they could be employed or by awarding them higher wages than apprentices and improvers. Annual increments were also specified for improvers and apprentices. Not only did this secure an orderly progression from juvenile to adult rates, but it reduced the economic incentive for employers to keep youths at the same work year after year. As youths gained experience, they had either to be paid more or to leave, and at the end of their term they had to receive the journeyman's wage. Though in some cases it was alleged that employers simply dismissed older boys and replaced them by younger workers, elsewhere the progressive wage scale provided an incentive for employers to rotate young workers into more demanding jobs, if not to provide full formal training. ${ }^{51}$

A second step was to restrict the proportions of apprentices and improvers employed. The proportions of male apprentices were most commonly set at around one to each three or four journeymen, but there were wide variations: at one extreme, the Bread Trade Board and the Woollen Board allowed rather more than one apprentice or improver for each two journeymen, while at the other the ratios in brickmaking, brewing and jam-making were 1:15, 1:25 and 1:50 respectively. These closure devices had an immediate impact; by the end of 1900 the proportion of boys employed in Wages Board trades was only about two-thirds that in the unregulated trades. ${ }^{52}$

The third step, unanimously desired by the trade unions but difficult to achieve, was the resuscitation of the apprenticeship system with all its paraphernalia of legally binding indentures. Foremost among the craft unions' concerns was their desire to see 'the abomination known as the improver system ... swept away'. ${ }^{53}$ To this end, at least seven Wages Boards specified higher wages for improvers than for apprentices, hoping to induce masters to indenture their juvenile hands. In a few other cases restrictions were placed on the number of improvers. Employers, however, remained largely unconvinced. It was received wisdom that boys 'behave better when they are not bound'. ${ }^{54}$ And in any event, as one boot manufacturer put it, 'the apprenticeship system is almost dead, owing very largely to the subdivision of labour'. ${ }^{55}$ De-skilling had made the old style of craft apprenticeship quite anachronistic. Under the new factory regime,

\footnotetext{
${ }^{50}$ For general comments on this see the Conference of Trades submission to RCFS, presented by J. Lemmon at q. 12785.

${ }^{51}$ See e.g. ibid., qq. $4683,7626-7,8752$ and statement by H. Mathews at q. 386 .

52 The proportions in Board and other trades in 1900 were $18.4 \%$ and $28.1 \%$ of the male workforce respectively (calculated from CIFS, 1900).

${ }_{53}^{5} \mathrm{~J}$. Lemmon to RCFS, q. 12785.

54 Ibid., evidence of W. Braithwaite, q. 5607; cf. S. King evidence at qq. 8507-8.

${ }^{55} \mathrm{Ibid}$., evidence of T. Harkness, q. 6790.
} 
apprenticeship could function only as a closure device; its technical content had been so attentuated that it could be revived in the old trades only in form, not in substance.

The very process of classification used to delimit the scope for juvenile labour involved a tacit acceptance of de-skilling. The categories of work specified in the Boards' determinations were themselves products of subdivision and mechanisation. On the Woodworkers' Board, for example, wage categories were based on the particular machines and other tools used, and the very danger of using the machines was the linchpin of the union's attempts to establish the work as a preserve for adult men. ${ }^{56}$ Other determinations assumed the existence of a high level of specialisation. The Pottery Trade Board provided 27 categories for adult men's wages. The Woollen Board set wages within 19 broad categories. The Plate Glass Board established 13 categories, distinguishing between three classes of glaziers, four of cutters and two of embossers, as well as setting rates for cementers, bevellers, silverers and men turning out lead from the mill. The Brick Board distinguished between 24 categories of adult workers. For many of the craft unions, this minute system of differentiation represented an abandonment of, or at least a tactical retreat from, their earlier insistence on the unity of the labour process.

Sometimes this also entailed a retreat from craft elitism. The equalisation of wages for hand- and machine-workers in the boot trade, for example, laid the basis for a dissolution of the deep divisions that had emerged in the trade during the early $1890 \mathrm{~s}^{57}$ By contrast, the Printing Trade Board's scale for linotype operators represented a bid for a craft monopoly of the new technology. Not only was the minimum for linotype operators, at 70 s for a 42 hour week, the highest for any category of workers under the Boards, but the minimum for linotype apprentices and improvers was set at 60 s for the first six years, while employers were allowed to put hand compositors on to the machines as probationers for a wage of only 49s. In giving permanency to the temporary wage advantage linotype operators had enjoyed by virtue of the scarcity of their skills in using the newly introduced machine, ${ }^{58}$ the determination probably helped to limit the spread of the new technology.

A common thread of many of these determinations was thus their tendency to stabilise the division of labour, reclaim jobs for men and put a brake on the helter-skelter mechanisation which, in the boot trade at least, had become so rapid that new machines were being superseded in a matter of a year or two. ${ }^{59}$ As the jam manufacturers complained in their protests against the Tinsmiths' Board's decisions, the Board had deliberately set out to

${ }^{56}$ See J. Sutch to RCFS, q. 10667 et passim. Cf. jam trade employees' petition at VPRS 5466, 11.

${ }^{57}$ On which see Operative Bootmakers' Union, T5/1/3, 29 July and 12 August 1895, 16 July 1896. ${ }^{58} \mathrm{~J}$. Hagan, Printers and Politics: A History of the Australian Printing Unions, Canberra 1966, pp. 104, 148.

${ }^{59}$ RCFS, evidence of W. Cabena, q. 7556. 
curtail the use of labour-saving machinery and stamp out female operatives, although as we need not point out, all progress in mechanical arts has had for its incentive the cheapening of production by the substitution of labour-saving machinery, calling for less skill and attention on the part of the operatives. ${ }^{60}$

This was an overstatement. The intention was seldom to prevent labour-saving machinery being used, but rather to exact for workingmen a share in the resultant productivity gains.

These moves gained active support from sections of manufacturing capital. The scenario varied from trade to trade. In some cases, as in printing, clothing and furniture, the nucleus of support came initially from established union employers who wished to boost their share of the market. This alliance, broadly along the lines of that envisaged by the Act's liberal proponents, nevertheless proved short-lived; as is clear from the case of the furniture trade, these employers were not prepared to tolerate the use of the Boards to effect significant wage improvements in their own factories, and virtually none actively supported the Boards by 1902-3. A less predictable but more enduring source of support for the employees on the Boards came from small employers at the 'quality' end of their trades who were still using craft methods and feared that they were being left behind by their competitors. Most also catered primarily for a local market, and had long recognised the relationship between high wages and strong domestic demand. Their motivation, however, was not entirely economic: as their evidence to the 1901 Royal Commission attested, many had a strong sense of themselves as initiates to the crafts and shared with the unions a powerful craft culture, whose linchpins were a view of the craft as a lifetime vocation or 'calling', a belief in the moral necessity of workmen receiving a living wage, a devotion to high standards of workmanship and an attachment to an order of workplace relationships in which boys knew their place and women, if they were admitted at all, were segregated into clearly defined, subordinate roles. ${ }^{61}$

Labour's other potential allies on the Boards were the chairmen, several of whom married a belief in the social importance of men receiving living wages with an abiding suspicion of the moral and physical effects of factory employment on women and children. ${ }^{62}$ Harrison Ord, the Chief Inspector of Factories, shared many of these values. Ord exerted a considerable influence over the progress of wage regulation, especially in controversial cases. To take two determinations with practically identical effects - those of the Tinsmiths' and Brushmakers' Boards - in the former case Ord opposed the determination on the grounds that it would prejudice intercolonial trade, and the determination was never put into effect; in the latter case, the determination was enforced with

${ }^{60}$ Jam manufacturers' statement, 3 April 1902 in VPRS 5466, 193.

${ }^{61}$ On the first set of allies see e.g. Fitzgerald, op.cit., pp. 84-5; on the master craftsmen in various trades see Ord's trade summaries and comments on Wages Board applications in VPRS 5466, 19, 37, 193; employers' correspondence at ibid., 8; RCFS, qq. 7586, 8006, 8143, 8193, 8551, 11926.

${ }^{62}$ See for example T. Bride to RCFS, qq. $12567 \mathrm{ff}$; A. Edgar to Royal Commission into Old Age Pensions, op. cit., q.321. 
Ord's support, the Chief Inspector arguing for women's exclusion on the grounds that 'it would be no great hardship if these girls did have to leave the trade whereas if the men are driven out they and their families will be in the position of highly skilled workmen whose skill has suddenly become useless' ${ }^{63}$

Such support was clearly sectional: it was support for the claims of working men in the name of support for the working class. Here we have a situation that broadly accords with Heidi Hartmann's argument for the centrality of the family wage in the reconciliation of capitalism and patriarchy. ${ }^{64}$ The family wage, backed by 'protective' legislation and, in this case, a thoroughgoing intervention in the division of labour within the factories, represented a bargain struck between male workers and certain capitalists (though not, it must be noted, the capitalist class as a whole), with the support of the 'liberal' professional stratum.

Juveniles and working women had no such allies, in spite of the heartrending tales of exploitation proffered by the anti-sweating movement. It was simply assumed that they, too, would ultimately benefit from the stabilisation of men's wages. Nor, significantly, did women and juveniles have strong unions to back up their claims or monitor the enforcement of the Wages Board determinations. The situation was further complicated by the fact that, when women did venture to express an opinion, they were often divided among themselves. In a number of cases where female workers' jobs were threatened, they did protest to the Board in question or the Chief Inspector. These protests, however, were often instigated by the employers, and little heed was paid to them. On the other hand, there were many women who supported the enforcement of the family wage. In the hat-making trade, for example, the women employed as trimmers and binders joined with the men to oppose the use of juvenile labour. There was an element of altruism in some women's attitudes towards wage regulation. Thus 'Mrs A.', one of the anonymous witnesses to the 1901 Commission, supported the Clothing Board's determination for the sake of the wage increases it gave to other members of her family, even though it is clear from the tenor of her evidence that it had actually reduced her own earnings. ${ }^{65}$

It was, in fact, in the clothing trades that the contrast between the impact of state regulation on men's and women's work was most apparent. To begin with, the lowest-paid, all-female dressmaking and millinery trades were only brought under Wages Boards after 1905. Of the sections of the trade that were regulated earlier, underclothing and shirt-making were also preponderantly female. The Boards for both set wage minima at a mere 16 s per week for adult women and allowed employers to start young girls at $2 \mathrm{~s} 6 \mathrm{~d}$ per week. While the Shirt Board did at least restrict the proportions of learners to one for each three adults, the

63 Ord to T.F. Bride, 10 September 1902, in VPRS 5466, 193; Ord to Peacock, 30 July 1902, in VPRS 5466, 19.

${ }^{64} \mathrm{H}$. Hartmann, "The unhappy marriage of Marxism and feminism: towards a more progressive union', in L. Sargent (ed.), Women and Revolution, Boston 1981, esp. pp. 20-2.

${ }^{65}$ RCFS, qq. $13947 \mathrm{ff}$. For examples of women's protests see VPRS 5466 , 19; 193; the trimmers' petition is in the Federated Felt Hatters' Union Collection, Melbourne University Archives. 
Underclothing Board allowed two learners for each adult hand. Here, as elsewhere, the plea that large numbers of learners were needed to replace women who left work on marriage, though increasingly at odds with women's actual behaviour, was enough to ensure that more learners were permitted than in male trades.

The Underclothing and Shirt Boards also provided for piece-payment. However, the first Underclothing Board reached complete deadlock on the piece-rate scale. When a new Board finally brought down a determination in 1899 , it effectively allowed manufacturers to set their own piece-rates. Though the scale adopted was supposed to allow an average hand to earn the 16s minimum wage, the fact that in 1900 the average earnings of adult pieceworkers were only $14 \mathrm{~s} 11 \mathrm{~d}$ suggests that the manufacturers were being less than scrupulous in assessing 'average' production. ${ }^{66}$ Furthermore, the fact that the workers were not organised made it easy for manufacturers to breach the Boards' provisions.

By contrast, in the manufacture of men's and boys' clothing, where men still had a strong presence, the main initial thrust of the Wages Board was to centralise production in factories. Here, as with the Furniture Board, the large employers and master craftsmen joined with the labour representatives to put a stop to the multiplication of outworkers and reduce competition. The piecerates in the clothing trade were raised substantially. Even after one of the master tailors voted with the labour representatives for a 20 s rate for women working indoors, manufacturers found it a paying proposition to shift the bulk of their production into factories. ${ }^{67}$

The principal beneficiaries of the Clothing Board's determinations were the craftsmen, both masters and employees. Both stood to gain from the elimination of under-cutting by middlemen supplying work to outdoor hands. The master tailors, who already paid their highly skilled hands better than the minimum, faced no higher wage bills, while the male employees consolidated their hold over the best-paid work, secured a limitation on learners and improved their own prospects of earning a steady income. The gains for the women in the trade are, to say the least, problematic. The outworkers, who alone had no representatives on the Board, were the biggest losers: though nominal rates were increased, the centralisation of production in factories meant that women whose family commitments made it impossible for them to shift to indoor work lost the meagre livelihood they had previously earned. Some retreated to the poorly paid underclothing, shirt and dressmaking trades. ${ }^{68}$ Wages for the indoor female hands did rise considerably. But, as will be discussed below, the employers promptly introduced new methods which made sure that the women paid in

${ }^{66}$ Figures from CIFS, 1900.

${ }^{67}$ RCFS, qq. 7700, 1954, 8001, 8158.

${ }^{68}$ Blencowe's evidence to RCFS, q. 7729. The restrictions on learners had a similar effect (Barrett to RCFS, q. 7954). 
sweat for the extra shillings they earned. And again, the proportion of female learners allowed was much larger than for men.

The same broad tendency was evident in printing and bootmaking, the two major trades outside textiles in which women were entrenched. In all these trades the Wages Boards gave permanency to the segregation of women within the trade and their exclusion from the elite branches. ${ }^{69}$ The minimum wages set, though often higher than the rates ruling earlier, were sufficient only for a workwoman to support herself, and any hope of women strengthening their industrial bargaining position was neutralised by the generous allowances made for the employment of learners.

Food processing was the other major area of female employment covered by Wages Boards. Here again, the coverage was only partial: the jam and confectionery trades had Boards, but not the manufacture of grocers' sundries and biscuits. The food processing trades represented the new face of Victorian industrial capitalism. Their very expansion marked a significant extension of capitalist production into an area in which domestic, non-market production had previously been dominant. Capital in these trades was highly concentrated, and production was strongly export-oriented. The factories were far larger than the Victorian average of about 13 hands per establishment: in 1901, the mean number of employees in confectionery factories was 38 , in jam over 63 , in grocers' sundries 22 and in biscuits a massive $181 .^{70}$ All these industries had taken subdivision to an extreme, and their methods of production closely resembled modern assembly-line techniques. All employed numerous women and juveniles; the proportion of adult men in the factory workforce in 1901 was 30 per cent in the jam trade, 29 per cent in biscuits and grocers' sundries and 19 per cent in confectionery. Within the factories there was a rigid division of labour along gender lines. Women were very poorly paid: for adult women, average wages ranged from $11 \mathrm{~s} 11 \mathrm{~d}$ in confectionery to $15 \mathrm{~s} 3 \mathrm{~d}$ in biscuit-making and grocers' sundries, while the range for adult men was from $32 \mathrm{~s} 10 \mathrm{~d}$ in jammaking to $36 \mathrm{~s} 7 \mathrm{~d}$ in biscuit-making. ${ }^{71}$

Though nominally all had unions, there were formidable obstacles to the improvement of wages in these industries. The rigid factory discipline, ruthless victimisation of malcontents, and the lack of any continuity of trade union tradition among the women and juvenile workers prevented the unions from gaining more than a toe-hold. Furthermore, a state regulatory apparatus based on trade coverage could only approach these large, diversified companies in a piecemeal manner. And the factory proprietors had organising traditions of their own. In biscuit-making, for example, the leading manufacturers had long maintained a price cartel, ${ }^{72}$ and among the manufacturers' ranks were num-

${ }^{69}$ See determinations at CIFS, 1900; the female rate in the boot trade was set on the chairman's casting vote.

70 CIFS, 1901.

${ }^{71}$ Ibid.

72 See T.B. Guest letterbooks, 1888ff., Melbourne University Archives, especially correspondence with F.T. Derham. 
bered F.T. Derham and several other stalwarts of the increasingly aggressive Victorian Employers' Federation. The jam manufacturers showed their capacity for united action after the Tinsmiths' Board passed its first determination. They moved on two fronts, making vigorous representations to the Minister and simultaneously combining to force down the prices offered to fruitgrowers, claiming that losses on wages would have to be made up elsewhere. Predictably, the fruitgrowers then joined in the campaign against the determination. ${ }^{73}$

There was no substratum of small manufacturers with which the workers could ally themselves on these Boards. Though the parvenu Rosella company occasionally broke ranks with the older manufacturers, ${ }^{74}$ its position was not materially different from the rest. And it was comparatively easy for the foodstuff manufacturers to sway 'liberal' Wages Board chairmen with the argument that, as large exporters, they were locked into a national price structure which made it impossible for wages to be raised locally without damaging interstate markets. ${ }^{75}$

The impact of wage regulation on these industries was consequently small. The manufacturers conceded slight pay increases as a result of the Pastrycooks' and Confectioners' determinations, but the Tinsmiths' Board determination was not applied to the jam and biscuit factories. And on the Jam Board, alone of all the Wages Boards, an employee representative defected to vote for a determination which set the minimum for men at only $30 \mathrm{~s}$ and for women at a mere $14 \mathrm{~s}$. It was later alleged that the defector was the only employee representative who still had a job after the determination was passed. ${ }^{76}$ The Jam and Confectioners' Board determinations were also conspicuous for the complete absence of any restrictions on the employment of juveniles at general work and for the wide differentials they entrenched between male and female rates of pay. In confectionery, for instance, the male labourers' wage of $40 \mathrm{~s}$ was far ahead of the rate paid adult women for 'best work', which stood at only $17 \mathrm{~s}$.

There was another dimension to the unevenness of the Wages Boards' impact. The system depended on the existence of a minimal level of employer consent, which was not always forthcoming. In the sugar industry, the Colonial Sugar Refining Company successfully forestalled several campaigns for a Wages Board between 1899 and 1913 by threatening to move its operations to Sydney each time the subject was raised. ${ }^{77}$ The master fellmongers were consistently obstructive, boycotting the Board, sacking employee representatives and locking out the entire workforce in protest against the determination. Later the master fellmongers were the first to use the Industrial Appeals Court to have key provisions in the determination overturned. ${ }^{78}$ Thus, far from assisting workers who were unable to improve their position by industrial action, the Wages Board

${ }^{73}$ VPRS 5466, 111 and 193. ${ }^{74}$ Rosella Co. to Peacock, 29 March 1902, in ibid., 111 ; cf. Trades Hall Council Minutes, 19 August
1898.

${ }^{75}$ See manufacturers' protests at 5466, 193.

${ }^{76}$ RCFS, evidence of S. Barker, q.8207. 77 VPRS 5466, 186 (E. Knox to Ord, 22 April 1901 et passim); cf. Kitchen's obstruction in soap-
making (VPRS 5466, 26). 
system contributed towards entrenching and codifying disparities within the working class.

To arrive at any general assessment of the impact of state wage regulation in this early, experimental stage, it is necessary to step back a little and consider the problem in the context of the wider processes of capital accumulation, the evolution of the division of labour within the working class and the orientation and dynamics of the trade union movement. In many respects the effects were uneven, often contradictory. This seems particularly to have been the case where the dynamics of capital accumulation are concerned. In the short term, the introduction of the Boards was followed by a certain amount of disinvestment as manufacturing capital sought to escape the net. Coupled with the widespread uncertainty about the effects of the impending federalisation of tariffs, this helped to create an atmosphere of crisis which could be used to justify the emasculation of the Board system. However, in a longer perspective, state regulation can be seen as actively fostering the accumulation and concentration of capital. This was especially the case where the Boards effected a shift from subcontracting to direct employment. But more generally, the setting of minimum wages made it more difficult for under-capitalised 'mushroom' enterprises to erode the market share of the larger firms. Furthermore, higher wage levels and the supersession of piece-rates by regular weekly wages spurred employers to experiment with a variety of measures to increase the 'density' of the working day. One of the most common devices was the institution of 'task' work, where the workers were required to meet high production targets before they would be paid the minimum wage. This system was widespread in the boot, clothing and furniture factories by the turn of the century. ${ }^{79}$ Mechanisation and subdivision also continued apace, one notable feature being the increasing use of electricity as a source of power. As Mary Wyse, a Wages Board representative, described the consequences in the clothing factories, the workwoman 'is not supposed to leave her seat until she leaves off' ${ }^{80}$

An early casualty of this intensification of work pressure was the 'independence' of those craftsmen whose high piece-rates had previously allowed them some freedom to set their own pace and working hours. In their eyes the emphasis on speed represented not only an imposition but a threat to accepted standards of workmanship. ${ }^{81}$ There were also other, more serious casualties. Workers who, by virtue of some disability, of age or of inadequate training, could not keep up to the mark were widely dismissed. Though ageing workers could apply to the Chief Inspector of Factories for special permits to work at sub-minimum rates, this provision was not widely used; it was

78 See Davey, op.cit., pp. 67, 103; also RCFS, qq. 4940, 5053, 5066-8, 5085-6, 5398, 5426.

${ }^{79}$ On the task system see for example RCFS, qq. 7606, 7866-7, 8231, 9646.

80 Ibid., q. 8254.

${ }^{81}$ Ibid., qq. 7528, 12785. 
humiliating for the applicants, and Ord, intensely aware of the dangers of permits being abused, refused to grant them in large numbers. ${ }^{82}$ When employers complained that, with the Wages Boards, Parliament had 'construed a public demand to suppress sweating into an excuse for establishing a condition of affairs that can best be described as an aristocracy of labour', ${ }^{83}$ they were not referring to an aristocracy of craftsmen over unskilled workers but to an aristocracy of men at the height of their powers over others who were physically unable to compete on an equal footing.

The centralisation of production in factories and the increasingly rigid workdiscipline applied also militated against the wider employment of married women. As outworkers, women had at least been able to combine child-rearing and household management with paid labour. To combine household labour with a forty-eight hour week of factory work, by contrast, imposed an insupportable burden which women with children would undertake only in extremis. The dissociation of paid labour from the home not only disadvantaged women who were sole breadwinners, but also reduced the scope for women whose husbands were poorly paid to supplement the family's income by taking work in. In turn, the enforced transience of women in the workforce provided added justification for their continuing segregation into the worst-paid jobs, giving greater permanency to the lines of demarcation which had been codified by the Wages Boards.

The advent of state regulation also had important consequences for the labour movement. It is inconceivable that the trade unions could have managed by industrial action alone to re-establish the boundaries between men's, women's and boys' work as swiftly and decisively as they did with the assistance of the state. The unions' weakness on the ground was highlighted in 1901-3 by their complete inability to mount any resistance to employer victimisation; delegates on at least five of the Boards were sacked by their employers and apparently black-listed, but the unions appear to have been incapable of taking action to have them reinstated. ${ }^{84}$

With their early successes in reclaiming the key sections of the labour process for men and establishing a structure which broadly expressed men's prior claims to a breadwinner's wage, the unions were able to consolidate themselves as vehicles for the expression of workingmen's industrial concerns, while retaining much of the exclusivist character of their craft origins. The possible implications of this extend well beyond the scope of this study. Only a few lines of argument can be suggested here. First, the reclaiming of de-skilled industrial work for men rested on a fundamentally arbitrary system of classification and demarcation which not only entrenched divisions within the workplace, but also had to be constantly renegotiated as the reorganisation of the labour process continued, involving the trade unions in constant struggle among themselves and reinforc-

${ }_{82}^{82}$ Ibid., especially Ord's evidence at q. 11951.

${ }^{84} \mathrm{lbid}$., V. Stooke, q. $1500 ;$;f. J. Rosier, q. 580.

${ }^{8}$ Ibid., qq. 8207, 10295, 10416, 12513 ; VPRS 5466, 193, J. Keleher to Ord, 18 November 1903. 
ing their dependence on the state to effect labour market closure. Secondly, the industrial labour movement's agenda continued to be dominated by the problem of securing a 'fair day's work for a fair day's pay', where the concept of 'fairness' applied was in both cases predicated upon a social division of labour in which men's primary responsibility to their families was expressed, not within the home, but in the capitalist labour market. Within this framework, the labour movement could offer no fundamental challenge to the construction of wage labour as an intensive, exclusive activity which was quite incompatible with the assumption of day-to-day responsibility for the affairs of a household.

At times the division of labour along age and gender lines within the workplace appears to conform so precisely to, and so neatly reinforce, the patterns of authority within the household that it is tempting to take it as a preordained and integral feature of capitalist social relations. To do so, however, is to neglect the active role played by the industrial labour movement and its allies in shaping that division of labour. The developments described here represent only a moment in the continuing process of challenge and reconstruction through which the division of labour within the family has been constituted simultaneously as a buffer against the most obvious forms of capitalist exploitation, a fundamental source of cleavage within the working class and a powerful constraint on oppositional tendencies within the labour movement. 


\section{University Library}

\section{- M M I E R R VA A gateway to Melbourne's research publications}

Minerva Access is the Institutional Repository of The University of Melbourne

Author/s:

Lee, Jenny

Title:

A re-division of labour: Victoria's Wages Boards in action

Date:

1987

Citation:

Lee, J. (1987). A re-division of labour: Victoria's Wages Boards in action. Historical Studies, 22(88), 352-372.

Publication Status:

Published

Persistent Link:

http://hdl.handle.net/11343/34353 